\title{
The Common Agricultural Policy and the EU budget: stasis or change?
}

Alan Greer, University of the West of England

\begin{abstract}
This article evaluates the reform of the EU's Common Agricultural Policy, set within the context of negotiations about the Multi-annual Framework for 2014-20. It traces the reform process from the proposals presented by the Commission in $2010-$ encapsulated as 'convergence, capping and greening' - to the outcomes eventually agreed in 2013 after inter-institutional bargaining. The conclusion is that the reform outcomes highlight that the CAP remains resistant to substantial change, both in terms of its budget and in its main policy instruments. This incremental change is explained in institutional terms. First, the balance of institutional forces within the EU, especially the member states and the continuing power of the agricultural interest, still works to insulate the CAP against pressures for radical reform. There is a continuing cleavage between advocates of substantial change and a much larger bloc of member states who favour the retention of the 'traditional' CAP. Second, the new institutional setting of co-decision, which increased the role and influence of the EP, reinforced the dominant 'state-assisted' conception of agricultural policy.
\end{abstract}

\section{JEL classification}

Q18; H230

\section{Keywords}

Agricultural Policy, CAP reform, Multi-annual Financial Framework, co-decision 


\section{Introduction}

Agriculture has always provided a fertile field for students of politics and public policy, especially those of us fascinated by how the political power of farmers in Europe has persisted despite the long gradual decline in their number and the relative economic importance of the sector. This is reflected in the fact that the Common Agricultural Policy (CAP) not only has received the lion's share of EU level spending over the years, but that it continues to do so. The durability of the CAP and farm spending in the face of pressures for its substantial reduction, and the fact that it continues to be important for many member states, gives a highly political edge to debates about its reform. It is partly for these reasons - the size of the farm budget and the relative resistance to change of the CAP - that the agriculture sector is of interest for scholars of the EU as well as those seeking to explain the durability of public policies generally.

Much of the academic literature on the CAP and comparative agricultural policy generally has tended to emphasise its 'exceptional' nature and its relative resistance to change, underpinned by an institutional balance of forces that favours the agricultural interest, both in respect of national governments and societal groups representing producers (see for example Coleman et al 1997, Grant 1997, Rieger 2000, Roederer-Rynning 2010, Skogstad 1998). Of course this does not mean that change is impossible, and over the long term, incremental change can have substantial cumulative effects. Rather what is at issue is the speed, extent and direction of change. Burrell (2009) charts a pattern of continuous reform of the $\mathrm{CAP}$, from a highly centralized protectionist policy focused on farm incomes to one that is more market sensitive and environmentally sustainable, and in which governments have greater scope to adapt the overall framework to their particular national conditions (see also Greer 2005). However it would be a mistake to see policy change as a historically driven one-way process. Daugbjerg (2009), for example, uses the notion of 'sequencing' to show how changes to the CAP over time are often reactive but not necessarily in the same direction and that each reform event opens possibilities for further reform.

CAP reform episodes since the late 1980 s - such as the MacSharry reforms in 1992, the Agenda 2000 reforms in 1999 and the Fischler package in 2003 - have provided insightful case studies of the speed and scale of change, the endogenous institutional forces at play, and importance of exogenous factors such as enlargement and world trade liberalisation (see Ackrill 2000a, Cunha 2011, Keeler 1996, Swinbank 1999, and Swinnen 2009). Typically CAP reform outcomes are viewed as incremental change, the outcome of bargaining between actors in which the key factors are the preferences and institutional structures of member states, with the Commission also playing a crucial role in setting the reform agenda.

Reflecting the wider contemporary interest in the role of ideas in the policy process, some authors emphasise the link between the changing ideational context and the shape of reform outcomes (Lynggaard and Nedergaard (2009). Also drawing on the importance of policy ideas, Daugbjerg and Swinbank (2009) point to the importance of trade agreements, notably the Uruguay Round Agreement on Agriculture (URAA), in the development of the CAP, especially in establishing the market liberal paradigm as the ideational underpinning of agricultural trade. Yet they still caution that this sits awkwardly with the continued dominance of the stateassisted paradigm as the foundation of the CAP. Erjavec et al (2008) also have noted how the policy discourse of Agriculture Commissioners (Fischler and Fischer-Boel) exhibited a rhetorical shift from a largely mercantilist to a neo-liberal perspective. Subsequently, however, some have argued that the tenure of Commissioner Cioloş has witnessed something of a reversal back to the stateassisted position that defended farm subsidies as a way to ensure a fair and efficient European agriculture (Rutz et al, forthcoming). 
Budgetary considerations have played a key role in agricultural policy change, sometimes bringing the issue onto the policy agenda and opening a policy window for CAP reform, for example the crisis of over-production in the 1980s. Ackrill (2000b) has argued that EU budgetary rules and expenditure limits can work to constrain CAP reform. In addition, he uses ideas about historical institutionalism and path-dependence to explore the linkages between institutional reform of the budget and change in the CAP, especially in the period 1988-92. While these concepts are ideally suited to explain the resilience of agricultural policy, they need to be joined with the notion of 'institutional layering' to explain the how largely pathdependent processes can experience reform (Ackrill and Kay 2006a).

This relationship can be seen clearly in the negotiations on the multi-annual financial framework (MFF) for 2014-20, and a parallel round of CAP reform, both of which concluded in 2013. In the MFF case, debates about the overall level of the EU budget, and of the place of agriculture within it, were centre-stage, framed by the context of economic austerity. On CAP reform the core questions concerned how best to reshape the policy to meet contemporary concerns, for example about fair treatment for all member states and the deepening of environmental sustainability, related crucially to the overall budgetary envelope. A crucial factor that influenced both process and outcomes was the changed institutional setting. As well as the contemporaneous discussions on the budget, the CAP reform debates took place within the new institutional arrangements introduced in the Lisbon Treaty, which extended the co-decision procedure to the CAP and arguably has enhanced the influence of the European Parliament (EP). Indeed the 2013 CAP reform dossiers were the first major test of these new institutional arrangements.

After first summarising the budgetary context and the historical trends on the funding of the CAP, this article sets out the outcomes of the MFF for 2014-20, highlighting changes in the proposed allocations during the negotiations. It then traces the CAP reform process between 2010 and 2013 in light of the initial proposals presented by the Commission. It concludes that the outcomes of the reform process were less radical than originally envisaged. This relative pathdependence and incremental change is explained in institutional terms. First, the balance of institutional forces within the EU, most especially the policy preferences of the main policy actors - especially the member states and the continuing power of the agricultural interest - still works to insulate the CAP against pressures for radical reform. There is a continuing cleavage between member states, which maps onto a broader budgetary gainers/losers division, between advocates of radical reform and those who favour the retention of the 'traditional' CAP. Second, the new institutional setting of co-decision, which increased the role and influence of the EP, reinforced the 'traditional' conception of the purpose and shape of agricultural policy. The central conclusion is that the outcomes of the reform processes highlight that the CAP still remains resistant to substantial change, both in terms of the level and distribution of its budget, and in its main policy mechanisms and instruments, despite demands from some quarters for a radical reconfiguration of policy to take a more focused 'public goods' approach.

\section{CAP spending in historical perspective}

Agriculture has always consumed a big slice of the EU budget, reflecting that the CAP historically has been the most important 'common' policy. In the late 1970s around 75 per cent of total spending went to agriculture but since then the trajectory has been downwards. By the first year of the 1988-92 financial period the CAP still took up 60 per cent of spending, despite reforms to the budget that made it 'redistributive and less CAP-oriented' (Laffan and Lindner 2010, p. 217). By the late 1990s farm expenditure fell to around half, reflecting successive reforms to the CAP and the expansion of the EU into areas such as cohesion, regional and social policy. By the late 2000s the CAP budget (now including rural development) still 
represented around 40 per cent of the total but is projected to continue on a gradual downwards trajectory (for a fuller discussion see Greer 2012).

Annual budgets for agriculture and rural development are set within the overall framework of the EU's multi annual financial frameworks. In the MFF for 2007-13, around 43 per cent of a total $€ 976 \mathrm{bn}$ went to the "preservation and management of natural resources', mainly the CAP. Although total spending did not fall by much over the MFF, the agriculture budget continued its relative decline because of the expansion of competences and increased expenditure in other areas. By the final year of the MFF in 2013 the proportion of the EU budget devoted to the CAP had fallen to around 40 per cent (€60bn) (see figure 1).

Figure 1: EU budget 2013

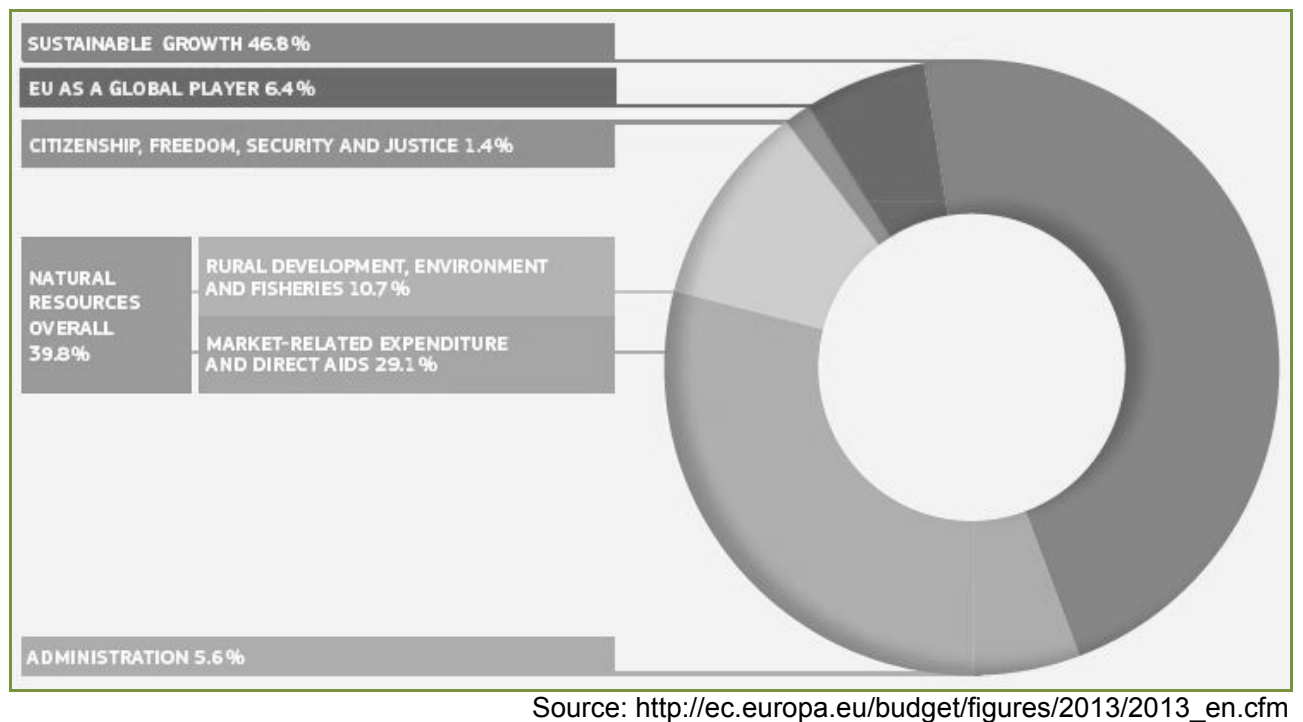

The distribution of these substantial resources for agriculture and rural development has always been a matter of contention, especially around spending on environmental sustainability. In the 2007-13 MFF one third of the total budget (around 80 per cent of CAP spending) went to 'traditional' direct payments and market intervention in agriculture (pillar 1) while the remainder was for measures on the environment and rural development (pillar 2). To use the Commission's somewhat misleading language, by 2013 'agricultural' spending had declined to around 30 per cent of the total budget, although this is something of an 'accountancy trick' because almost all of pillar 2 expenditure goes to farmers and landowners under the auspices of the CAP. So despite a falling share, spending on the CAP remains substantial. As the Commission acknowledged, 'agriculture is, in budgetary terms, the second most important Union policy, and the only fully integrated policy at Union level' (EU Commission 2011b).

\section{The Multi-annual Financial Framework 2014-2020}

Discussions about CAP reform took place in tandem with negotiations about the MFF for 2014-20, both framed by financial crisis and the 'austerity agenda'. The draft MFF unveiled by the Commission in June 2011 envisaged spending of $€ 1025$ billion, an increase of nearly five per cent. Following difficult negotiations, in February 2013 the European Council agreed an MFF that was widely referred to as the first ever budget 'cut' in the history of the EU (although previous MFF saw 'cuts' in terms of percentage gross national income (GNI)(see Benedetto and Milio 2012, p. 180). Inter-institutional negotiations between the EP, Council and Commission produced a compromise political agreement in June 2013. Table 2 illustrates the proposals and outcomes of the negotiations at various stages prior to the final inter-institutional agreement. An overall ceiling of $€ 960 \mathrm{bn}$ (commitment 
appropriations) was agreed, a reduction of around three per cent in 2011 prices over previous period and of eight per cent on the Commission's proposals.

Explanations of the outcomes of budget negotiations usually emphasise the relative influence of core actors and institutions at both the supranational and national levels. For Laffan and Lindner (2010) the European Council 'is the dominant player', with the Commission trying to play the role of 'honest broker' (2010, pp. 213-4). As Swidlicki et al. also note the EU budget has proved difficult to reform 'because it is not primarily designed to maximise economic returns across Europe, but rather to balance a range of political interests. Member states are keen to protect areas of the budget from which they do well...' (2012, p. 6). A usual approach is to classify member states in terms of whether they are 'net contributors' (countries who pay out more than they get back such as the UK, Sweden, Finland and Germany) or 'net beneficiaries' (such as Greece and Portugal) in terms of the EU and CAP budget (with sometimes a third category of countries who pay in more or less as much as they receive (including Belgium, Denmark, France and Italy)(see de Wilde 2012, p. 1081; Swidlicki et al 2012, pp. 79).

On the 2014-2020 MFF, the net contributors resisted a budget increase, highlighted in a letter to Commission President Barroso in December 2010 in which David Cameron, Angela Merkel and other leaders argued that EU spending 'cannot be exempt from the considerable efforts made by the Member States to bring their public spending under control.' Specifically the next MFF 'should not exceed the 2013 level with a growth rate below the rate of inflation' (Cameron et al. 2010).

Table 2. MFF 2014-2020: comparisons (€m)

\begin{tabular}{|c|c|c|c|c|c|}
\hline $\begin{array}{l}\text { Commitment appropriations } \\
\text { In million euros (2011 prices) }\end{array}$ & $\begin{array}{l}\text { MFF 2007- } \\
2013\end{array}$ & $\begin{array}{l}\text { MFF 2014- } \\
2020 \\
\text { Commission } \\
\text { proposal June } \\
2012\end{array}$ & $\begin{array}{c}\text { MFF 2014- } \\
2020 \\
\text { European } \\
\text { Council } \\
\text { conclusions } \\
08.02 .2013 \\
\end{array}$ & $\begin{array}{c}\text { European } \\
\text { Council } \\
\text { conclusions } \\
\text { vs } \\
\text { MFF 2007-2013 }\end{array}$ & $\begin{array}{c}\text { European } \\
\text { Council } \\
\text { Conclusions } \\
\text { vs } \\
\text { Commission } \\
\text { Proposals } \\
\end{array}$ \\
\hline & & & & million euros (\%) & million euros (\%) \\
\hline $\begin{array}{l}\text { Total commitment } \\
\text { appropriations }\end{array}$ & 994.176 & 1.045 .282 & 959.988 & $-34.188(-3 \%)$ & $-85.294(-8 \%)$ \\
\hline $\begin{array}{l}\text { as a percentage of GNI } \\
\text { 1. Sustainable Growth }\end{array}$ & $\begin{array}{c}1,12 \% \\
446.310\end{array}$ & $\begin{array}{c}1,09 \% \\
503.310\end{array}$ & $\begin{array}{c}1,00 \% \\
450.763\end{array}$ & $\begin{array}{c}-0,12 \% \\
+4.453(+1 \%)\end{array}$ & $\begin{array}{c}-0,09 \% \\
-52.547(-10 \%)\end{array}$ \\
\hline $\begin{array}{l}\text { 1a. Competitiveness for } \\
\text { Growth and Jobs }\end{array}$ & 91.495 & 164.316 & 125.614 & +34.119 (+37\%) & $-38.702(-24 \%)$ \\
\hline $\begin{array}{l}\text { of which: Connecting Europe } \\
\text { Facility }\end{array}$ & 12.783 & 40.249 & 19.299 & $+6.516(+51 \%)$ & $-20.950(-52 \%)$ \\
\hline $\begin{array}{c}\text { of which: Galileo, ITER and } \\
\text { GMES }\end{array}$ & 8.047 & 15.548 & 12.793 & $+4.746(+59 \%)$ & $-2.755(-18 \%)$ \\
\hline $\begin{array}{l}\text { 1b. Cohesion for Growth and } \\
\text { Employment }\end{array}$ & 354.815 & 338.994 & 325.149 & $-29.666(-8 \%)$ & $-13.845(-4 \%)$ \\
\hline $\begin{array}{c}\text { of which: Investment for } \\
\text { growth and jobs }\end{array}$ & 345.935 & 327.116 & 313.197 & $-32.738(-9 \%)$ & $-13.919(-4 \%)$ \\
\hline $\begin{array}{l}\text { of which: European territorial } \\
\text { cooperation }\end{array}$ & 8.880 & 11.878 & 8.948 & $68(+1 \%)$ & $-2.930(-25 \%)$ \\
\hline 2. Preservation and & & & & & \\
\hline $\begin{array}{l}\text { Management of Natural } \\
\text { Resources } \\
\text { of which: market related }\end{array}$ & 420.682 & 389.972 & 373.179 & $-47.503(-11 \%)$ & $-16.793(-4 \%)$ \\
\hline $\begin{array}{l}\text { expenditure and direct } \\
\text { payments }\end{array}$ & 318.820 & 286.551 & 277.851 & $-40.969(-13 \%)$ & $-8.700(-3 \%)$ \\
\hline of which: rural development & 95.741 & 91.966 & 84.936 & $-10.805(-11 \%)$ & $-7.030(-8 \%)$ \\
\hline $\begin{array}{l}\text { 3. Citizenship, freedom, } \\
\text { security and justice }\end{array}$ & 12.366 & 18.809 & 15.686 & $+3.320(+27 \%)$ & $-3.123(-17 \%)$ \\
\hline 4. EU as a global player & 56.815 & 70.000 & 58.704 & $+1.889(+3 \%)$ & $-11.296(-16 \%)$ \\
\hline 5. Administration & 57.082 & 63.165 & 61.629 & $+4.547(+8 \%)$ & $-1.536(-2 \%)$ \\
\hline 6. Compensations & 920 & 27 & 27 & $0(0 \%)$ & $0(0 \%)$ \\
\hline
\end{tabular}


Negotiations between the member states on the MFF reflected core national interests and revolved around established issues such as the UK 'rebate' and the level of funding for the CAP. Here the relationship between the UK and France is again instructive. With the government under pressure from a sizeable number of euro-sceptic Conservative MPs, the UK wanted at least a freeze, if not a substantial cut, in the total MFF but also to defend its 'rebate' (see House of Commons Library 2013, p. 7). Although outgoing President Sarkozy (but not President François Hollande) at times supported a freeze in spending, he disagreed with the UK on the extent of 'cuts' and in the areas they should fall. While there were suggestions that Cameron and Sarkozy had agreed informally that the UK would not push too hard for CAP reform if France did not demand cuts in the rebate (The Guardian, 28 May 2012), Hollande questioned the justification for the British rebate and brought Italy and Spain into a troika of 'refuseniks' in an effort to fend off a substantial reduction in the MFF and to protect agricultural spending.

Overall the consensus of opinion favoured budgetary constraint, although there was disagreement about the scale of 'cuts'. The pivotal role was played by German Chancellor Angela Merkel who came down in favour of a squeeze on spending. For one commentator, the negotiations created 'an impression of earnest endeavour that paved the way for a victory for the austerity agenda of David Cameron and Angela Merkel' (Wyles 2013). Certainly the British government presented the MFF outcome as a major diplomatic triumph, both in terms of protecting the rebate and securing a cut in the budget - what Cameron referred to as 'Europe's seven-year credit card limit' (although it was also acknowledged that the UK's net contributions will still rise because the rebate does not cover increased spending in new member states).

\section{CAP Reform and the MFF 2014-2020}

Reaching agreement on the MFF is only the beginning of the story. Perhaps more important are the debates about how a smaller cake is to be divided up, whether between countries or sectors,

\section{The CAP after 2013: the MFF context}

Debates about CAP reform after 2013 took place within the context of the negotiations on the draft MFF. This was something of a departure on previous experience because reforms of the CAP have tended to take place 'outside the framework of the big budget bargains' (Laffan and Lindner 2010, p. 224). Agriculture spending for 2007-13, for example, was fixed by the Chirac-Shroeder deal in 2002 and independently of the main MFF negotiations on the MFF (see Greer 2012, p. 106). During the debate on the MFF, some reformist voices advocated a radical shift of the EU's budgetary priorities to fund increased spending on sustainable growth in areas such as employment, research/development and energy, rooted in a conviction that most CAP spending does not promote the attainment of public goods (Greer 2012, pp. 111-2). One proposal advocated a switch in funding from the CAP to better targeted spending on issues such as energy and climate change (Núñez Ferrer, 2009). A complete and radical overhaul of the EU also was recommended in a report by the relatively Euro-sceptic Open Europe, whose 'alternative budget' proposed a reduction of spending by almost a third while focusing the smaller budget that remained 'far more effectively on boosting jobs and growth' (Swidlicki et al, 2012, p. 3).

Yet arguably the agreement on the MFF changed little despite the rhetoric and reality of cuts. For one commentator the negotiations produced a budget agreement 'that helps farmers but will do little to create growth and jobs' (Wyles 2013). Certainly the distribution of 'cuts' in relation to the Commission's original proposals fell heavily on areas such as 'citizenship' (17 per cent), the 'EU as a 
global player' (16 per cent) and crucially proposed expenditure on 'sustainable growth' was reduced by 10 per cent $(€ 50 \mathrm{~m})$ on the proposals, with the 'competitiveness for growth and jobs' heading reduced by 24 per cent $(€ 38 \mathrm{~m})$, and funds for the 'connecting Europe' facility within this slashed by over half, although on this still represented increases on the previous MFF.

That a radical reconfiguration of the budget away from the CAP was unlikely had been evident from the Commission's draft MFF which explicitly acknowledged that 'a significant part of the EU budget should continue to be dedicated to agriculture, which is a common policy of strategic importance', and that the CAP share of funding be maintained at the 2013 level (2011c, p. 7). Nevertheless the actual resources available for the CAP will be reduced. In the initial proposals $€ 379 \mathrm{bn}$ was earmarked for the CAP ( 37 per cent of the total), compared with $€ 415 \mathrm{bn}$ in the previous MFF. After the Council agreement, this figure was adjusted marginally downwards to $€ 363 \mathrm{bn}$, representing a reduction of around 12 per cent on the previous MFF, and an extra cut of 4-5 per cent on the Commission proposals (see table 2). There will be real reductions in agricultural spending, which will go down in real terms and also as a percentage of the total budget (predicted to fall to around 37 per cent by 2020). While consistent with the pattern of continued gradual decline, however, this does not represent the fundamental restructuring EU spending and its core priorities that the radical reformers have argued for.

Within this overall context, a the MFF agreement broadly maintains the 75:25 spending ratio between pillar 1 direct payments/market measures and pillar 2 rural development/environmental sustainability. The Commission proposal earmarked 76 per cent to direct payments and 24 per cent to rural development; in the Council conclusions these figures were roughly maintained although the reduction for rural development was eight per cent compared with four per cent in direct payments. Expressed in current prices, proposed annual expenditure from 2014 is stable, although commitment appropriations on market support and direct payments will still make up 30 per cent of the EU budget in 2014 and 27 per cent in 2020 (see table 3).

Table 3. MFF 2014-2020: commitment appropriations ( $€ m$ )

MULTIANNUAL FINANCIAL FRAMEWORK (EU-28)

\begin{tabular}{|c|c|c|c|c|c|c|c|c|}
\hline COMMITMENT APPROPRIATIONS & 2014 & 2015 & 2016 & 2017 & 2018 & 2019 & 2020 & $\begin{array}{l}\text { Total } \\
2014-2020\end{array}$ \\
\hline 1. Smart and Inclusive Growth & 63.972 & 66.812 & 69.304 & 72.342 & 75.270 & 78.751 & 82.466 & 508.918 \\
\hline 1a: Competitiveness for growth and jobs & 16.457 & 17.553 & 18.345 & 19.794 & 21.095 & 22.927 & 25.026 & 141.197 \\
\hline 1b: Economic, social and territorial cohesion & 47.434 & 49.171 & 50.864 & 52.447 & 54.065 & 55.707 & 57.316 & 367.005 \\
\hline 2. Sustainable Growth: Natural Resources & 59.304 & 59.598 & 59.908 & 60.191 & 60.267 & 60.344 & 60.422 & 420.035 \\
\hline of which: Market related expenditure and direct payments & 44.130 & 44.368 & 44.628 & 44.863 & 44.889 & 44.916 & 44.942 & 312.737 \\
\hline 3. Security and citizenship & 2.179 & 2.246 & 2.378 & 2.514 & 2.655 & 2.801 & 2.950 & 17.723 \\
\hline 4. Global Europe & 8.335 & 8.750 & 9.142 & 9.432 & 9.824 & 10.269 & 10.509 & 66.261 \\
\hline 5. Administration & 8.721 & 9.076 & 9.483 & 9.919 & 10.346 & 10.787 & 11.254 & 69.585 \\
\hline of which: Administrative expenditure of the institutions & 7.056 & 7.350 & 7.678 & 8.008 & 8.360 & 8.700 & 9.071 & 56.224 \\
\hline 6. Compensations & 29 & 0 & 0 & 0 & 0 & 0 & 0 & 29 \\
\hline TOTAL COMMITMENT APPROPRIATIONS & 142.539 & 146.482 & 150.215 & 154.398 & 158.363 & 162.952 & 167.602 & 1.082 .551 \\
\hline as a percentage of GNI & $1,03 \%$ & $1,02 \%$ & $1,00 \%$ & $1,00 \%$ & $0,99 \%$ & $0,98 \%$ & $0,98 \%$ & $1,00 \%$ \\
\hline $\begin{array}{r}\text { TOTAL PAYMENT APPROPRIATIONS } \\
\text { as a percentage of GNI }\end{array}$ & $\begin{array}{r}135.866 \\
0,98 \%\end{array}$ & $\begin{array}{r}141.901 \\
0,98 \%\end{array}$ & $\begin{array}{r}144.685 \\
0.97 \%\end{array}$ & $\begin{array}{r}142.771 \\
0,92 \%\end{array}$ & $\begin{array}{r}149.074 \\
0,93 \%\end{array}$ & $\begin{array}{r}153.362 \\
0,93 \%\end{array}$ & $\begin{array}{r}156.295 \\
0.91 \%\end{array}$ & $\begin{array}{c}1.023 .956 \\
0.95 \%\end{array}$ \\
\hline
\end{tabular}

Source: House of Commons Library 2013, p. 9.

\section{CAP Reform after 2013: the proposals}

Between April 2010 (when it initiated preliminary discussions) and October 2011 (the publication of detailed legislative proposals), the EU Commission's Directorate General for Agriculture and Rural Development (DG Agri) formulated proposals for 
a reformed CAP after 2013. The aim was to take the opportunity provided by the new MFF to 'refocus the CAP on its core and new activities' (European Commission, 2011a, p. 15). Resources would be better targeted with a 'greener and more equitably distributed first pillar' with a second pillar 'more focussed on competitiveness and innovation, climate change and the environment' (European Commission, 2011a, p. 16). The goal is to promote a 'new partnership between Europe and its farmers' through creating a CAP that will 'strengthen the competitiveness, sustainability and permanence of agriculture throughout the EU in order to secure for European citizens a healthy and high-quality source of food, preserve the environment and develop rural areas' (Europa, 2011).

Based on the belief that there remained widespread support for a strong CAP structured around its two pillars, DG Agri set out three broad policy scenarios that struck different balances between them. An 'adjustment scenario' envisaged 'further gradual changes', while a 'refocusing scenario' would usher in far reaching reform, with a substantially reduced budget centred on environmental and climate change objectives. For the Commission however, the first option would not adequately address the challenges of the future, whereas the second would 'come at a significant social and environmental cost' (European Commission, 2011c, pp. 5-6; 2011d, p. 38; 2010a, p. 12). Consequently the preferred approach was a midpoint 'integration scenario' that would 'make major overhauls of the policy in order to ensure that it becomes more sustainable, and that the balance between different policy objectives, farmers and Member States is better met' (European Commission, 2010a, p. 12 original emphasis). As fleshed out in policy specifics in the Commission's legislative proposals, this approach has three main elements that are intended to alter the distribution of spending within the CAP: convergence, capping, and greening (see Swinbank 2012).

'Convergence' aimed to promote fairness by progressively narrowing variations in direct payments between farmers and across countries, particularly between old and 'new' Europe, to ensure both 'a more equal distribution of direct support' and 'fairer treatment of farmers performing the same activities' (European Commission, 2011a, p. 16). A unified 'basic payment scheme' would be phased in and replace the existing plethora of systems by 2019. National envelopes for direct payments will be adjusted so that countries receiving less than 90 per cent of the EU average payment will see one third of the gap closed.

'Capping' proposed the progressive reduction of payments received by large beneficiaries and holdings, with resources transferred to rural development (sometimes referred to as degressivity). Reductions would start at 20 per cent for entitlements between $€ 150,000$ and $€ 200,000$, gradually increasing in three stages to a 100 per cent reduction for payments over $€ 300,000$.

'Greening' was to be substantially enhanced by making 30 per cent of direct support (pillar 1 ) conditional on verifiable and legally defined 'environmentally supportive practices' with farmers 'receiving payments to deliver public goods to their fellow citizens' (European Commission, 2011a, p. 16). These practices were to include practices such as crop diversification, maintenance of permanent pasture, and the preservation of ecological reserves and landscapes. Countries would be able to transfer up to five per cent of direct payments between pillars to reinforce rural development, although for those whose level of direct payments is below 90 per cent of the EU average, 'reverse' transfer to pillar 1 will be allowed.

\section{The CAP after 2013: explaining the outcomes}

For Laffan and Lindner, the three financial perspectives since early 1990s did little more than facilitate incremental changes in the levels of spending on the CAP (2010, p. 218). While farm spending will go down, analysis of the MFF for 20142020 supports this picture, with agriculture still accounting for over one third of the total EU budget. Two main ideas usually are offered to explain this: the relative 
balance of influence between member states as reflected in the outcomes of bargaining, and the nature of inter-institutional governance in the EU, both of which are overlaid by an enduring structural power enjoyed by agricultural interests. Because the CAP still takes up over a third of the budget, there is an overlap between 'net recipient' countries and a bloc of 'CAP defenders', which Swidlicki et al estimate at 24 countries. Although probably an over-exaggeration, around 20 countries defended the CAP at an Agriculture Council meeting in March 2011, greeted by French agriculture minister, Bruno Le Maire, as not just a 'strong political signal of support by governments for the CAP' but for 'strengthening it in the years to come' (Euractiv.com, 2 June 2010, 18 March 2011). Most member states generally favour maintaining CAP funding at around its current level, although they do differ about what the money should be spent on. For Swidlicki et al., this is 'a powerful bloc which continues to block reform under the influence of the farm lobby, the Commission, and many MEPs' (2012, p. 9).

This draws attention to the importance of EU institutions such as the EP, which has a formal role on CAP under the Lisbon Treaty and which has tended to favour the maintenance of agricultural spending at around its current level (see Greer \& Hind 2012). The Agriculture Council - historically the key actor on the CAP - typically has been regarded as defending the interests of farmers. As Swidlicki et al. pithily summarise, 'through the Commission's agenda-setting powers and the Parliament's veto powers, the EU institutions are also an obstacle to reforming the budget' (2012, p. 9). This, however, understates the extent to which the Commission actually has at times been an influential actor in promoting CAP reform.

\section{National interests and preferences}

Negotiating outcomes on the CAP and MFF reflect compromise and bargaining between different national interests but fundamental disagreements between member states remain extremely important. As Agra Europe noted in a report on an informal meeting of agriculture ministers in Spain in June 2010, 'calls for an end to Pillar One largesse were echoed by more liberal-leaning member states... while traditional defenders of the CAP budget made clear their continued support for a strong CAP despite the new budgetary austerity sweeping across Europe' (No. 2415, 4 June 2010).

Traditional CAP defenders such as France, Ireland and Greece support maintenance of the farm budget, favour direct payments tied to past levels of production, and remain sceptical about 'greening'. In early 2011, for example, President Sarkozy made it clear that France aimed to 'maintain the CAP's budget to the last euro' and stated that 'we do not have to excuse ourselves for defending Community preference and the CAP budget' (Euractiv.com, 19 January 2011; Le Monde.Fr, 12 May 2011). A crucial element in the political process on CAP reform, as it was in 2002, was the Franco-German axis. In a joint paper in September 2010 they set out agreed core principles for 'a strong CAP beyond 2013', rejected any 'renationalization', supported retention of the two pillar structure and of direct payments, and opposed substantial redistributive measures towards convergence' (Bundesministerium et al, 2010, p. 2). This was reinforced by a joint communique issued after a meeting in Berlin in October 2012 by agriculture ministers, Ilse Aigner and Stéphane Le Foll, which rejected calls from Britain, Poland and others for substantial cuts in pillar 1 expenditure. Both ministers also stressed the need to maintain 'close and trustful relations during the final stages of negotiations over CAP reform and the MFF' (Euractiv.com, 11 October 2012). France also joined with Spain in defence of farm spending. In February 2012 their agriculture ministers issued a statement that stressed the importance of maintaining a strong agricultural sector and made clear they would 'not accept' any budget that 'does not guarantee the stabilisation of the CAP' or maintain the existing level of spending (Euractiv.com, 15 February 2012). 
Reflecting their general stance on the MFF, pro-reform countries such as the UK, Sweden, Denmark and the Netherlands outlined radical reform ideas that were predicated to a degree on budgetary restraint. Recognising that substantial cuts in the short term were unlikely, they pressed for a substantial reorientation of support from pillar I (direct payments) to funding for the provision of public goods under pillar 2 in relation to rural development, the environment and climate change. In September 2011 for example, the agriculture ministers of the UK and Poland called for 'deep and genuine' reform of the CAP, centred on a more competitive agriculture sector and better incentives to improve the environment, with reduced emphasis on Pillar 1, convergence of direct payment rates, and a 'step change' in measures to increase competitiveness, including support under Pillar 2. This was described in one report as London and Warsaw putting themselves 'firmly on a collision course with France' over CAP reform (Euractiv.com, 22 October 2011).

\section{Preferences \& outcomes}

The extent of the influence of the 'reformers' can be assessed by mapping the extent to which they were successful in translating policy preferences into outcomes, using the UK as an exemplar. The UK historically has been in the vanguard of those favouring radical reform of the CAP. While governments of all party complexions have not advocated the total abolition of the CAP, which they see as vital to free trade within an undistorted single market, they do want a much less expensive, more consumer friendly, and more market oriented agricultural policy that is better focused on core objectives such as competitiveness and the environment. This means that reform must be radical and extensive, phasing out direct income support payments and shifting emphasis to pillar 2 funded public goods in the overall context of a smaller agricultural budget that has greater cofinancing. Whether this would resemble anything like the CAP as we have come to know it is open to doubt.

As the Department for the Environment, Food and Rural Affairs (DEFRA) noted in its response to the Commission's reform communication in January 2011, 'successive reforms of the CAP have set a direction of travel towards greater market orientation and agricultural competitiveness and a greater focus on the delivery of public benefits in return for CAP expenditure. The UK wants to see the acceleration of this process...' (Defra 2011b: 1). For the UK the Commission's proposals did not go far enough in two respects. First they insufficiently recognised the changed economic circumstances in the wake of the financial crisis. With intense pressure on public finances, the CAP 'cannot be immune to the hard choices being made elsewhere in the EU' and consequently there must be 'a very substantial cut to the CAP Budget' for the next MFF, concentrating on Pillar 1 and leaving pillar 2 with 'a greater share of a smaller CAP budget' (House of Commons, 2011a, p. 5). Second, by not taking the radical re-focusing' route the Commission proposals were 'insufficiently ambitious for engendering the change in EU agriculture sector that will be needed if it is to survive in an increasingly competitive international agricultural market' (House of Commons, 2011a, p. 4). Specifically the UK was concerned that proposals such as capping payments and greening Pillar 1 'would be counterproductive to EU aims to develop a competitive agriculture sector, and risk entrenching continued reliance on subsidies instead of independence.' Rather there is 'scope for Pillar 2 to better reward farmers for the important public goods they provide' and that we 'need to stimulate a change in behaviour rather than entrench continued reliance on subsidy which it is increasingly difficult for the European taxpayer to afford' (Defra, 2011b: para. 7). The UK therefore argued strongly for phasing out of the remaining coupled subsidies, an end to export subsidies and market support measures such as intervention, and a radical reorientation of spending from pillar 1 to pillar 2, involving the gradual abolition of direct payments to reduce spending substantially. 
So how does the outcome on CAP reform map onto such policy preferences? As one report put it, the CAP deal was finally reached on 26 June 2013 'after months of haggling over how ambitious the policy would be on overhauling direct payments, ending quotas, and making farmers more environmentally accountable' (Euractiv.com, 11 July 2013). Key issues were the reform of direct payments and the pillar 2 budget, the abolition of market support measures, capping, convergence and the plans for 'greening' pillar 1.

First, it is clear that advocates of radical reform did not succeed in obtaining the substantial reduction in the budget that they desired. Agriculture Council ministers broadly backed the Commission's reform ideas, noting for example in March 2011 that the CAP had to remain a strong common policy with financial resources commensurate with its objectives (Euractiv.com, 18 March 2011). The share of agriculture spending in the new MFF will still be around a third and will decrease only slowly. So a common reaction has been that 'agriculture was spared from major cuts made elsewhere in the EU's spending framework' (Euractiv.com, June 2013).

Second, the 75:25 spending ratio between the pillars remains and will not change much, if all, by 2020. If anything, the Council conclusions on the MFF have resulted in a relatively greater reduction of planned spending on pillar 2 than in pillar 1 . This indicates that when the budgetary circumstances are tight, governments and stakeholders resort to protecting their core interests ('there are no votes in pillar 2'). Arguably 'net contributors' such as the UK prefer overall budgetary constraint to a reconfigured CAP, which might actually cost more in the short term. So while Cameron played up his 'success' on the MFF, this came at the expense of failure to move the CAP substantially in the British government's favoured direction. Indeed on some calculations the MFF outcome has reduced the UK's resources under pillar 2 by more than originally planned.

Third, there was a mismatch on direct payments between the UK's long-term vision for the CAP and its specific negotiating priorities. While the government argued that income support subsidies are neither desirable nor necessary, it 'made it clear that phasing out such payments by 2020 is unrealistic, in both practical and negotiating terms' (House of Commons, 2011a, p. 6). Instead the aim was for 'a very substantial, transitional reduction followed by ultimate abolition at a later date' (Defra, 2011b, para. 12). This chimed with the Environment, Food and Rural Affairs Committee's recommendation for 'a more pragmatic approach' because ending direct payments 'is unachievable in the short-term' and sticking rigidly to this policy 'reduces the UK's ability to engage constructively with other Member States and could diminish the UK's influence in this round of reform' (2011b, p. 41). Essentially this recognises that while the UK does not like direct payments, most other countries do. In fact there are important voices in the UK who challenge the policy approach, which in many respects reflects a Treasury driven-agenda that is ideologically opposed to 'subsidies'. The devolved adminstrations in Wales and Northern Ireland defend them, and stakeholders such as the National Farmers' Union (NFU) are sceptical that they can be substantially reduced without having a substantial detrimental impact on the viability of many British farms.

Fourth, the UK criticised the plans for 'greening' a substantial share of pillar 1 funding as too modest but also fundamentally flawed, and 'unlikely to deliver significantly greater or more ambitious environmental benefits than those that are currently delivered' (Defra, 2011b, para. 27). The 'greening' proposals were the subject of much haggling during the negotiations on CAP reform, what one source has called the subject of 'a high-pressure lobbying campaign' from both farmers and environmentalists (Euractiv.com, July 2013). Other national governments expressed concerns that the policies would be burdensome. While the French and German agriculture ministers said that they supported 'greening', they nonetheless wanted a 'flexible' system so that 'agriculturally sustainable use of areas of ecological interest may be possible' (Euractiv.com, 11 October 2012). The 
statement issued by France and Spain was even blunter, criticising the draft rules for 'greening' as 'not adapted to the challenges facing European agriculture' (Euractiv.com, 15 February 2012).

In the negotiations, both the Council and MEPs supported plans to introduce 'greater flexibility' into the farm subsidies system. This reflected some core concerns of farming stakeholder groups about 'being locked into standardised environmental rules despite the diverse landscape of European agriculture' (Euractiv.com July 2013). For others, including environmental groups, this meant watering down the proposed requirements for 'greening'. One commentator noted in the wake of the Council conclusions on the MFF that Commission 'is fighting a rearguard action to force farmers to work in a way that benefits the environment', and that the scheme 'was weakened as part of last week's grand bargain between EU leaders at their budget summit in Brussels' (Harrabin 2013). A spokesperson for BirdLife Europe complained that 'Europe is offered a budget that scales back investment in the environment and caters for the usual fat cats that have been milking the system until now'; for the Royal Society for the Protection of Birds (RSPB) 'wildlife across Europe will pay a heavy price for this terribly regressive deal' (as quoted in Harrabin 2013).

Under the CAP deal, 30 per cent of direct payments will still be contingent on meeting certain environmental criteria, however there will be no EU-wide performance standards and member states will have greater flexibility in implementation, for example about when to apply sanctions. In addition the political agreement introduced a range of exceptions relating to water pollution, crop diversification and environmental sustainability. Farms under 15 hectares do not have to comply with new requirements to create "ecological focus areas," which in the first instance will apply to five per cent of farmland in 2015, rather than the proposed seven per cent (this may still increase pending a review in 2017). For critics, more than one-third of all farmland and 89 per cent of farmers will be exempted from the rules. Farms of less than 10 hectares (one third of the total in the EU) are exempted from crop diversification rules aimed at improving soil quality, and farmers also remain outside some EU environmental and water pollution legislation. According to a spokesperson for BirdLife Europe this represented 'a major blow to those who championed a more sustainable, forwardthinking policy - one which would deliver for people and the environment as well as protecting the long-term interests of farming' (Euractiv.com, July 2013).

Fifth, capping direct payments, inspired by a desire to better support small farmers, also was an area of dispute. Similar proposals were fiercely resisted in previous reform episodes by countries such as the UK and France who have efficient and large scale enterprises. For DEFRA capping discourages greater competitiveness by restricting 'natural structural processes' such as amalgamation and consolidation (2011b, para. 23), and proposals for supporting small farms should concentrate on improving their underlying competitiveness. In the event the reform deal did stipulate that payments to those receiving more than $€ 150,000$ per year would be progressively reduced, but left unresolved the level of a limit on how much any farmer could receive. The new rules stipulate that each farmer receive at least 60 per cent of the average national or regional direct payment by 2019 , a reshuffling that advocates say will help smaller landholders. Measures also were introduced to help 'new entrant' farmers.

Sixth, some caveats were introduced around convergence and the forward march of 'liberalisation' was stalled in some respects, illustrating again the influence of the protectors of a traditional CAP. German, French and Spanish ministers had strong reservations about convergence, not least because any redistribution in favour of 'new' member states would entail reduction in the benefits received by their own farmers (a Commission estimate put this as high as a 7 per cent reduction in funding for French farmers). France and Spain wanted a more careful phasing in of convergence and complained that the 'magnitude' and 'pace' proposed by the 
Commission was 'not acceptable'. Nevertheless the CAP deal does provide for the gradual harmonisation of payments between old and new countries, requiring that no single state receives less than 75 per cent of the EU average by 2019.

On the other hand the force of renewed arguments about food security in a world made increasingly volatile by climate change underpinned decisions to retain some production quotas. Although the last remaining export subsidies were reduced to zero, facilitated by high world food prices, sugar quotas were extended until 2017 (two years later than their planned abolition) and a new vine planting scheme after 2016 was introduced, rather than withdrawal of protection for grape growers. As Julie Girling, agriculture spokeswoman for the British Conservative party, complained, 'old-fashioned market intervention is back in a big way, potentially taking us back to the bad old days of butter mountains and wine lakes' (Euractiv.com, 11 July 2013).

Constructing a balanced scorecard on all of these elements it seems clear that the result of the negotiations on CAP reform was to markedly water down the original proposals of the Commission in order to secure agreement between member states, each of whom had their own 'red lines' and negotiating objectives. In most respects this 'watering down' was at the expense of ideas such as 'greening' that are central to the proposals of the radical reformers, and consistent with objections raised by defenders of a 'traditional' CAP. One way this has been done is to continue the trend to give greater flexibility for member states and hence more scope for national variation (see Greer 2005). One analysis remarked that while the final agreement 'retained some' of the original goals, the inter-institutional negotiations produced an outcome that 'gave the 28 member states more leeway, including over new environmental performance rules' (Euractiv.com, 11 July 2013). This actually is consistent with the UK's argument that member states

should continue to be given the flexibility to allocate CAP funding in a way that best suits the requirements of their own regions and farming structures, providing it is consistent with the wider objectives of the CAP. A one-size fits all solution will restrict rather than facilitate, as well as adding significant complexity and costs (Defra, 2011b, para. 24).

\section{The CAP after 2013: the influence of co-decision}

The outcome of the CAP reform process can be explained in essentially traditional ways, mainly by focusing on the defence of important national interests by member states (acting on their own, bilaterally or in coalitions) usually under the continued influence of a domestic farm lobby. In addition the CAP deal (as with the MFF) embodies side payments and trade-offs between the main policy institutions and actors (for example increased budget rebates for the Netherlands and Austria, and extra rural development funding for several countries including Ireland). One new influence compared to previous CAP reform episodes was the part played by the EP, exercising the formal role given to it by the Lisbon Treaty. Although some relatively minor issues had already been processed using the new rules, the 2013 CAP reform was the first real test of these new inter-institutional arrangements (see Greer \& Hind, 2012).

The first point to make is that co-decision in agriculture, at least on the big policy issues, is likely to prolong the policy process. The inter-institutional deal reached in June 2013 came nearly two years (21 months) after the Commission published its legislative proposals. As one report put it, there was a 'slow decision-making process, highlighted by intense lobbying', which means that much of the agreement will not be implemented until 2015, requiring the Commission to introduce transitional arrangements to cover 2014 (Euractiv.com, 11 July 2013).

Second, as suggested in some early analyses of co-decision in agriculture, while the EP now has a greater formal role in the decision-making process, this - so far at least - has buttressed the status quo on the CAP rather than facilitate radical 
change (Greer \& Hind 2012). The EP's agricultural committee, Comagri, dominated by farming, landowning and rural interests, defended the CAP in the negotiations and played a key part in altering the original proposals in some respects. The debates over 'greening' showed up the structural divisions within the EP, 'leading to battles in Parliament between the more green-focused environmental committee and its agricultural counterpart' (Euractiv.com, 11 July 2013). Irish agriculture minister, Simon Coveney, who oversaw the final stages of negotiations during Ireland's EU Presidency, accepted that there had been 'inter-institutional frictions' but considered that 'we have found a balance that everyone can agree with'. Others welcomed the broadening out of the decision process to a wider range of actors rather than a handful of national leaders. At the very least MEPs exercised their formal authority, 're-writing parts of the European Commission's original farming proposal and working through 40 rounds of negotiations with national ministers and the Commission'. One French environmental campaigner even praised the inclusion of the EP as 'good for food democracy...It's not perfect, but it is better than in the past' (Euractiv.com, July 2013). On the other hand, a more obvious interpretation is that offered by a spokesperson for WWF who complained that the EP

has proven that it is not ready to handle its new full co-decision powers on the Common Agricultural Policy. At every turn the Agriculture Committee has tried to water down this reform. It even managed to throw out the few improvements the Parliament plenary had requested of them. (Euractiv.com, July 2013).

\section{Conclusions}

The parallel negotiations on a new MFF for 2014-20 and proposals for the reform of the CAP after 2013 introduced greater complexity into the picture. It is arguable for example that the priorities of the UK focused more on big picture reductions (or a 'freeze') in overall budget expenditure rather than the specifics of CAP reform. In budgetary politics, radical reform is much harder under conditions of constraint, and in this case the tight agreement on the MFF made it even more difficult to secure radical changes in the CAP. So the window that might have opened for the MFF to usher in radical CAP reform stayed well shut. From the outset it was clear that the MFF process would not lead to a radical reconfiguration of the EUs budget priorities. Although real cuts were made in the resources allocated to agriculture, the CAP continues to be a substantial beneficiary from the EU budget. Within this framework, the balance between the two pillars will stay broadly the same, with no real transfer of funds from direct payments to measures for rural development and environmental sustainability. If anything, the outcome of the negotiations actually was to water down the original proposals for enhanced environmental measures, achieved in some part by reinforcing the capacity for national variation, and to row back from the liberalisation agenda by reintroducing market intervention measures and allowing the retention of some coupled subsidies.

The 2013 CAP reform episode again highlights many of the core themes that are present in the extensive literature on agricultural policy in the EU. Although in many respects path-dependent, reform is not impossible but takes place in a largely incremental fashion that can nonetheless produce considerable change over time. There remains a tension between a state-assisted and neo-liberal paradigm that can fluctuate between reform episodes, and policy actors working within institutional frameworks negotiate on the basis of preferences, which in the case of many member states continue to be favourable to agriculture.

Essentially the decision rules and institutional structures around the CAP, plus the balance of forces between member states, still works as a barrier against radical policy change. Although some governments such as the UK continue to advocate fundamental change, these remain largely voices in the wilderness. Most member states support the retention of the familiar CAP and its main policy instruments and 
mechanisms. This preference has been buttressed, at least in the medium term, by the inclusion of the EP in the formal procedures of CAP reform. Exploiting its enhanced role in the decision-making process, the EP - so far at least - has worked to support the status quo on the CAP rather than facilitate radical change.

\section{References}

Ackrill, Robert (2000a) 'CAP reform 1999: a crisis in the making?', Journal of Common Market Studies 38(2): 343-53.

Ackrill, Robert (2000b) 'The European Union Budget, the Balanced Budget Rule and the Development of Common European Policies', Journal of Public Policy 20(1): 1-19.

Ackrill, Robert and Adrian Kay (2006a) 'Historical-institutionalist perspectives on the development of the EU budget system', Journal of European Public Policy 13(1): 113-33.

Ackrill, Robert and Adrian Kay (2006b) 'The EU Budget and the CAP: An Agenda for the Review?', EuroChoices 5(3): 20-25.

Benedetto, Giacomo (2013) 'The EU budget after Lisbon: rigidity and reduced spending?', Journal of Public Policy 33(3): 345-69.

Benedetto, Giacomo (2012) 'Introduction: A History of the European budget and the Possibilities for Reform', in Giacomo Benedetto and Simona Milio (eds.), European Union Budget Reform: Institutions, Policy and Economic Crisis. Basingstoke: Palgrave Macmillan, pp. 1-20.

Benedetto, Giacomo and Simona Milio (2012) 'Conclusion: Budget Policy, Past Experience and the Future' in Giacomo Benedetto and Simona Milio (eds.), European Union Budget Reform: Institutions, Policy and Economic Crisis. Basingstoke: Palgrave Macmillan, pp. 171-192.

Bundesministerium für Ernährung, Landwirtschaft und Verbraucherschutz, Ministere de L'alimentation de L'agriculture et de al Peche (2010) Franco German position for a strong Common Agricultural Policy beyond 2013.

Burrell, Alison. (2009) 'The CAP: Looking Back, Looking Ahead', Journal of European Integration 31(3): 271-89

Cameron, David et al. (2010) 'A letter from Prime Minister David Cameron and other European leaders to the President of the European Commission on 18 December 2010'. http://www.number10.gov.uk/news/letter-to-president-ofeuropean-commission/

Coleman, William, Grace Skogstad, Michael (1997), 'Paradigm Shifts and Policy Networks: Cumulative Change in Agriculture', Journal of Public Policy 16(3): 273301.

Cunha, Arlindo with Alan Swinbank (2011) An Inside View of the CAP Reform Process: Explaining the MacSharry, Agenda 2000, and Fischler Reforms. Oxford: Oxford University Press.

Daugbjerg, Carsten (2009), 'Sequencing in public policy: the evolution of the CAP over a decade', Journal of European Public Policy 16(3): 395-411.

Daugbjerg, Carsten and Alan Swinbank, 'Ideational Change in the WTO and its Impacts on EU Agricultural Policy Institutions and the CAP', Journal of European Integration 31(3): 311-27.

DEFRA (2011a) CAP Reform post 2013: Defra discussion paper on the impact in England of the EU Commission Regulatory Proposals for the Common Agricultural Policy Reform, post 2013. December 2011. 
DEFRA (2011b) UK response to the Commission communication and consultation: "The CAP towards 2020: Meeting the food, natural resources and territorial challenges of the future." January 2011.

Erjavec, Karmen, Emil Erjavec and Luka Juvancic (2008) 'New wine in Old Bottles: Critical Discourse Analysis of the Current Common EU Agricultural Policy Reform Agenda', Sociologia Ruralis 49 (1): 41-55.

Euractiv.com (11 July 2013) 'CAP 2014-2020: A long road to reform'. http://www.euractiv.com/cap/cap-reform-2014-2020-linksdossier-508393

Euractiv.com (11 October 2012) 'Franco-German statement on CAP (9 Oct. 2012)'. http://www.euractiv.com/cap/france-germany-agree-keep-eu-far-news-515325

Euractiv.com (15 February 2012) 'Spain joins France in bid to ring fence CAP budget', http://www.euractiv.com/cap/spain-joins-france-bid-ring-fenc-news-510824

Euractiv.com (22 September 2011), 'Britain, Poland join calls for 'radical' CAP reform'. http://www.euractiv.com/cap/britain-poland-join-calls-radica-news-507829

Euractiv.com (12 September 2011) 'Nine EU countries call for slim EU budget'. http://www.euractiv.com/euro-finance/eu-countries-call-slim-eu-budget-news-

507532

Euractiv.com (18 March 2011) 'Reformers left isolated in EU farm policy debate'. http://www.euractiv.com/cap/reformers-left-isolated-eu-farm-policy-debate-news503245

Euractiv.com (19 January 2011) 'Sarkozy: France needs no excuse to defend EU farm policy'. http://www.euractiv.com/cap/sarkozy-france-needs-excuse-defend-eufarm-policy-news-501411

Europa (2011) 'Press Release: The European Commission proposes a new partnership between Europe and its farmers', IP/11/118, 12 October 2011.

European Commission DG Agriculture \& Rural Development (2010), Communication, The CAP towards 2020: meeting the food, natural resources and territorial challenges of the future (Brussels, 18.11.2010, Com (2010) 672 final).

European Commission (2011a) Communication from the Commission to the European Parliament, the Council, the European Economic and Social Committee and the Committee of the Regions, A Budget for Europe 2020, COM (2011) 500 final, Part I (Brussels, 29 June).

European Commission (2011b), EU Budget 2012: for 500 million Europeans. For Growth and Employment. http://ec.europa.eu/budget/library/biblio/publications/2012/budget_folder/budget_20 12_en.pdf

European Commission (2011c) Proposal for a regulation of the European Parliament and of the Council on the financing, management and monitoring of the Common Agricultural Policy, COM (2011) 628/3, 2011/0288 (COD), SEC (2011) 1153/4 (Brussels).

European Commission (2011d) Impact Assessment: Common Agricultural Policy towards 2020, Commission Staff Working Paper, XXX SEC (2011) 1153 (Brussels).

European Commission (2010) Communication, The CAP towards 2020: meeting the food, natural resources and territorial challenges of the future, Com (2010) 672 final (Brussels, 18 November).

European Parliament (2013) Resolution on the European Council conclusions of 7/8 February concerning the Multiannual Financial Framework', B7-0129/2013. 
Greer, Alan (2012) 'Reform of the EU Budget: Implications for the Common Agricultural Policy', in Giacomo Benedetto and Simona Milio (eds.), European Union Budget Reform: Institutions, Policy and Economic Crisis. Basingstoke: Palgrave Macmillan, pp. 103-121.

Greer, Alan and Tom Hind (2012) 'The Lisbon Treaty, agricultural decision-making and the reform of the CAP: an analysis of the nature and impact of 'co-decision', Politics and Society 31 (4): 331-41.

Greer, Alan (2005) Agricultural Policy in Europe. Manchester: Manchester University Press.

Grant, Wyn (1997) The Common Agricultural Policy. Basingstoke, Palgrave.

Harrabin, Roger (2013) 'EU budget deal for farmers raises wildlife concerns', BBC news 12 February 2013. http://www.bbc.co.uk/news/science-environment21424957.

House of Commons, Environment, Food and Rural Affairs Committee (2011a) The Common Agricultural Policy after 2013: Government response to the Committee's Fifth Report of Session 2010-11, Fifth Special Report of Session 2010-12, HC 1356. June 2011.

House of Commons, Environment, Food and Rural Affairs Committee (2011b) The Common Agricultural Policy after 2013, Fifth Report of Session 2010-11, HC 671, vols. I \& II. April 2011.

House of Commons Library (2013), EU Multiannual Financial Framework (MFF) 2014-2020, Standard note SNEP 6455, March 2013.

Keeler, John (1996) 'Agricultural power in the European Community: explaining the fate of CAP and GATT negotiations', Comparative Politics 28(2): 127-49.

Laffan, Bridget and Johannes Lindner (2010) 'The Budget: Who Gets What, When and How', in Helen Wallace, Mark A Pollack and Alistair Young (eds), Policy Making in the European Union (6th edition). Oxford, Oxford University Press, pp. 207-28.

Le Monde.Fr (12 May 2011) 'Sarkozy : "La France veut le maintien du budget de la PAC à l'euro près"'. http://www.lemonde.fr/europe/article/2011/05/12/sarkozy-lafrance-veut-le-maintien-du-budget-de-la-pac-a-l-euro-pres_1521067_3214.html.

Lynggaard Kennet and Peter Nedergaard (2009) 'The Logic of Policy Development: Lessons Learned from Reform and Routine within the CAP 19802003', Journal of European Integration 31(3): 291-309.

Núñez Ferrer, Jorge (2009) 'For a Future Sustainable, Competitive and Greener EU Budget: Integrating the Climate Change Objectives'. Final report of a CEPS Task Force. Brussels: Centre for European Policy Studies.

Paice, Jim (2011) http://www.defra.gov.uk/news/2011/08/26/cap-reform-meetings/.

Rieger, Elmar (2000) 'The Common Agricultural Policy: politics against markets', in Helen Wallace and William Wallace (eds), Policy-making in the European Union. Oxford, Oxford University Press, pp. 180-210.

Roederer-Rynning, Christilla (2010) 'The Common Agricultural Policy: the Fortress Challenged', in Helen Wallace, Mark Pollack and Alastair Young (Eds.), PolicyMaking in the European Union (6th ed.). Oxford: Oxford University Press, pp. 181206.

Roederer-Rynning, Christilla (2003) 'From "talking shop" to "working parliament"? The European Parliament and agricultural change', Journal of Common Market Studies 41(1): 113-35. 
Roederer-Rynning, Christilla and Frank Schimmelfennig (2012) 'Bringing codecision to agriculture: a hard case of parliamentarization', Journal of European Public Policy 19(7): 1-18.

Rutz, Cordula, Janet Dwyer and Jorg Schramek, (forthcoming) 'More new wine in old bottles? The evolving nature of the CAP debate in Europe', Sociologica Ruralis.

Skogstad, Grace (1998), 'Ideas, Paradigms and Institutions: Agricultural Exceptionalism in the European Union and the United States', Governance 11(4): 463-90.

Swidlicki, Pawel, Anna Kullmann and Mats Persson (2012) Seizing the Moment: Aligning the EU budget with Europe's economic needs. London: Open Europe. http://www.openeurope.org.uk/Content/Documents/Pdfs/2012EUbudget.pdf.

Swinbank, Alan (2012) 'Another Reform? Proposals for the post-2013 Common Agricultural Policy', World Agriculture: problems and potential, 3(1): 32-37.

Swinbank, Alan (1999) 'EU agriculture: Agenda 2000 and the WTO commitments', World Economy 22(1): 41-54.

Swinnen, J. (2009)(ed.) The Perfect Storm: The Political Economy of the Fischler Reforms of the Common Agricultural Policy. Brussels: Centre for European Policy Studies.

Swinnen, Jo and Louise Knops (2012) 'CAP Reform: Will the European Parliament take the bull by the horns?' CEPS Commentaries. Centre for European Policy Studies: Brussels. Available from www.ceps.eu

de Wilde, Peter (2012) 'Politicisation of the EU Budget: Conflict and the Constraining Dissensus', West European Politics 35(5): 1075-94.

Wyles, John (2013) 'An EU budget deal that sends the wrong signals', European Voice, 14 February 2013. http://www.europeanvoice.com/article/imported/an-eubudget-deal-that-sends-the-wrong-signals/76431.aspx. 